\title{
TGF- $\beta 1$ inhibits human trophoblast cell invasion by upregulating kisspeptin expression through ERK1/2 but not SMAD signaling pathway
}

\author{
Lanlan Fang ${ }^{\dagger}$, Yang Yan ${ }^{\dagger}$, Yibo Gao, Ze Wu, Zhen Wang, Sizhu Yang, Jung-Chien Cheng ${ }^{*}$ (1) and Ying-Pu Sun ${ }^{*}$
}

\begin{abstract}
Background: Tightly regulation of extravillous cytotrophoblast (EVT) cell invasion is critical for the placentation and establishment of a successful pregnancy. Insufficient EVT cell invasion leads to the development of preeclampsia (PE) which is a leading cause of maternal and perinatal mortality and morbidity. Transforming growth factor-beta1 (TGF$\beta 1)$ and kisspeptin are expressed in the human placenta and have been shown to inhibit EVT cell invasion. Kisspeptin is a downstream target of TGF- $\beta 1$ in human breast cancer cells. However, whether kisspeptin is regulated by TGF- $\beta 1$ and mediates TGF- $\beta 1$-suppressed human EVT cell invasion remains unclear.

Methods: The effect of TGF- $\beta 1$ on kisspeptin expression and the underlying mechanisms were explored by a series of in vitro experiments in a human EVT cell line, HTR-8/SVneo, and primary cultures of human EVT cells. Serum levels of TGF- $\beta 1$ and kisspeptin in patients with or without PE were measured by ELISA.

Results: TGF- $\beta 1$ upregulates kisspeptin expression in HTR-8/SVneo cells and primary cultures of human EVT cells. Using pharmacological inhibitor and siRNA, we demonstrate that the stimulatory effect of TGF- $\beta 1$ on kisspeptin expression is mediated via the ALK5 receptor. Treatment with TGF- $\beta 1$ activates SMAD2/3 canonical pathways as well as ERK1/2 and PI3K/AKT non-canonical pathways. However, only inhibition of ERK1/2 activation attenuates the stimulatory effect of TGF- $\beta 1$ on kisspeptin expression. In addition, siRNA-mediated knockdown of kisspeptin attenuated TGF- $\beta 1$-suppressed EVT cell invasion. Moreover, we report that serum levels of TGF- $\beta 1$ and kisspeptin are significantly upregulated in patients with PE.
\end{abstract}

Conclusions: By illustrating the potential physiological role of TGF- $\beta 1$ in the regulation of kisspeptin expression, our results may serve to improve current strategies used to treat placental diseases.

Keywords: TGF- $\beta 1$, Kisspeptin, KISS1, Trophoblast cells, Invasion

*Correspondence: jungchien.cheng@gmail.com; syp2008@vip.sina.com 'Lanlan Fang and Yang Yan contributed equally to this work.

Center for Reproductive Medicine, Henan Key Laboratory of Reproduction and Genetics, The First Affiliated Hospital of Zhengzhou University, 40, Daxue Road, Zhengzhou, Henan, China

\section{Background}

The placenta is a unique organ in eutherian mammals which plays a pivotal role in reproduction. Placental development is marked by extravillous cytotrophoblast (EVT) cells invading the uterine wall and spiral arteries, replacing the cells of the vessel wall and creating a high-flow low-resistance vessel that ensures a continuous blood supply to the placenta throughout pregnancy original author(s) and the source, provide a link to the Creative Commons licence, and indicate if changes were made. The images or other third party material in this article are included in the article's Creative Commons licence, unless indicated otherwise in a credit line to the material. If material is not included in the article's Creative Commons licence and your intended use is not permitted by statutory regulation or exceeds the permitted use, you will need to obtain permission directly from the copyright holder. To view a copy of this licence, visit http://creativecommons.org/licenses/by/4.0/. The Creative Commons Public Domain Dedication waiver (http://creativeco mmons.org/publicdomain/zero/1.0/) applies to the data made available in this article, unless otherwise stated in a credit line to the data. 
[1]. Uncontrolled trophoblast cell invasion is associated with choriocarcinoma and hydatiform moles $[2,3]$. In contrast, insufficient human trophoblast cell invasion into the uterine decidua and inadequate remodeling of the uterine vasculature leads to the development of preeclampsia (PE) which is a serious complication of pregnancy defined by high blood pressure and proteinuria $[3,4]$. Therefore, trophoblast cell invasion must be tightly controlled, and a better understanding of the regulation of this process as well as the underlying molecular mechanisms will improve the diagnosis and treatment of pregnancy-related disorders.

Kisspeptin encoded by the KISS1 gene was first identified as a human melanoma metastasis suppressor gene [5]. Therefore, the kisspeptin is also known as metastin which belongs to the family of RF-amide peptides. Kisspeptin is a placenta-derived hormone in humans [6]. Kisspeptin exerts its biological function by binding to a G protein-coupled receptor, GPR54 [7]. Kisspeptin and GPR54 are highly expressed in the human placenta that plays important role in the regulation of placentation [8]. It has been shown that kisspeptin inhibits migration and invasion in primary human trophoblast cells and human EVT cell line, HTR-8/SVneo [9-12]. In the placenta of PE patients, the expression levels of kisspeptin are upregulated when compared to that in the placenta of uncomplicated pregnancies [13].

Transforming growth factor-beta1 (TGF- $\beta 1$ ) belongs to the TGF- $\beta$ superfamily which regulates diverse cellular functions and is involved in the regulation of various physiological and pathological processes [14]. TGF- $\beta 1$ regulates cellular processes by binding to transmembrane type I and type II receptors [15]. In the canonical pathway, upon binding to receptors, TGF- $\beta 1$ activates SMAD2/3 signaling pathways [16]. In non-canonical signaling pathways, TGF- $\beta 1$ has been shown to act through MAPK and PI3K/AKT signaling pathways that are SMAD-independent [17]. TGF- $\beta 1$ and its receptors are expressed in the human placenta [18]. A previous study has identified that the KISS1 gene is a mediator of TGF- $\beta 1$-stimulated breast cancer cell invasion [19]. We and other groups have demonstrated that TGF- $\beta 1$ inhibits the human EVT cell invasion [20-23]. Given the anti-invasive effect of kisspeptin in human EVT cells, whether kisspeptin expression is regulated by TGF- $\beta 1$ and mediates the TGF- $\beta 1$-inhibited cell invasion remains unknown. Therefore, in the present study, we examined the effect and the underlying molecular mechanisms of TGF- $\beta 1$ on kisspeptin expression in human EVT cells. We also explored the role of kisspeptin in the TGF- $\beta 1$-inhibited EVT cell invasion and compared the serum levels of TGF- $\beta 1$ and kisspeptin between healthy and PE patients.

\section{Methods}

\section{Antibodies and reagents}

The KISS1 (\#ab226786) antibody was purchased from abcam. The ALK5 antibody was purchased from Invitrogen (\#PA5-78198). The phospho-SMAD2 (\#3108), phospho-SMAD3 (\#9520), SMAD2 (\#3103), SMAD3 (\#9523), and SMAD4 (\#38454), phospho-ERK1/2 (\#9106), ERK1/2 (\#9102), phospho-AKT (\#9271), and AKT (\#9272) antibodies were purchased from Cell Signaling Technology. The $\alpha$-tubulin (\#sc-23948) antibody was purchased from Santa Cruz Biotechnology. The recombinant human TGF- $\beta 1$ was obtained from R\&D systems. The SB431542, LY294002, and EGF were obtained from Sigma. The U0126 was obtained from Cayman. The kisspeptin-10 was obtained from Tocris.

\section{Cell culture}

The HTR-8/SVneo cell line was obtained from American Type Culture Collection through an official distributor in China (Beijing Zhongyuan Limited). HTR-8/SVneo is an SV40 large $\mathrm{T}$ antigen immortalized first-trimester short-lived extravillous trophoblast cell line [24]. Cells were cultured in a humidified atmosphere containing $5 \% \mathrm{CO}_{2}$ and $95 \%$ air at $37^{\circ} \mathrm{C}$ in Dulbecco's modified Eagle's medium/nutrient mixture F-12 Ham medium (DMEM/F-12; Gibco) supplemented with 10\% charcoal/ dextran-treated FBS (HyClone), $100 \mathrm{U} / \mathrm{mL}$ penicillin and $100 \mu \mathrm{g} / \mathrm{mL}$ streptomycin sulfate (Boster).

\section{Primary human EVT cell isolation and culture}

The study received institutional approval and was carried out in accordance with the guidelines from the Zhengzhou University Research Ethics Board (\#2020-KY-140). Human trophoblast cells were isolated from first trimester placental tissue explants as previously described $[20,23]$. Briefly, chorionic villi were washed with cold medium and mechanically minced into $1-2 \mathrm{~mm}$ fragments. Fragments of the chorionic villi were allowed to adhere for 2-3 days, after which any non-adherent material was removed. These tissue explants were further cultured for 10-14 days to allow trophoblast outgrowth, during which the culture medium was changed every 2 days. Trophoblast cells were separated from the villous explants by brief trypsin digestion. Cells were cultured in a humidified atmosphere containing $5 \% \mathrm{CO}_{2}$ and $95 \%$ air at $37^{\circ} \mathrm{C}$ in Dulbecco's modified Eagle's medium/nutrient mixture F-12 Ham medium (DMEM/F-12) supplemented with $10 \%$ charcoal/dextran-treated FBS, $100 \mathrm{U} /$ $\mathrm{mL}$ penicillin, and $100 \mu \mathrm{g} / \mathrm{mL}$ streptomycin sulfate. Individual primary cultures were composed of cells from one individual patient. Each experiment was repeated at least three times and each time used cells derived from different patients. 
Reverse transcription quantitative real-time PCR (RT-qPCR) Total RNA was extracted with the TRIzol (Invitrogen) according to the manufacturer's instructions. RNA $(1 \mu \mathrm{g})$ was reverse-transcribed into first-strand cDNA with the iScript Reverse Transcription Kit (Bio-Rad Laboratories). Each $20 \mu \mathrm{L}$ qPCR reaction contained 1X SYBR Green PCR Master Mix (Applied Biosystems), $60 \mathrm{ng}$ of cDNA, and $250 \mathrm{nM}$ of each specific primer. The following primers were used: KISS1, 5'-CAC TTT GGG GAG CCA TTA GA-3' (sense) and 5'-CAG TAG CAG CTG GCT TCC TC-3' (antisense); ALK5, 5'-GTT AAG GCC AAA TAT CCC AAA CA-3' (sense) and 5'-ATA ATT TTA GCC ATT ACT CTC AAG G-3' (antisense); SMAD4, 5'-TCC ACA GGA CAG AAG CCA TT-3' (sense) and 5'-GTC ACT AAG GCA CCT GAC CC-3' (antisense); Cx43, 5'-TAC CAA ACA GCA GCG GAGTT-3' (sense) and 5'-TGG GCA CCA CTC TTT TGC TT-3' (antisense); and GAPDH, 5'-GAG TCA ACG GAT TTG GTC GT-3' (sense) and 5'-GAC AAG CTT CCC GTT CTC AG-3' (antisense). qPCR was performed on an Applied Biosystems QuantStudio $12 \mathrm{~K}$ Flex system equipped with 96-well optical reaction plates. The specificity of each assay was validated by melting curve analysis and agarose gel electrophoresis of the PCR products. All of the RT-qPCR experiments were run in triplicate, and a mean value was used to determine the mRNA levels. Water and mRNA without RT were used as negative controls. Relative quantification of the mRNA levels was performed using the comparative $\mathrm{Ct}$ method with GAPDH as the reference gene and using the formula $2^{-\Delta \Delta C t}$.

\section{Western blot analysis}

Cells were lysed in cell lysis buffer (Cell Signaling Technology) supplemented with a protease inhibitor cocktail (Sigma). Equal amounts of protein were separated by SDS polyacrylamide gel electrophoresis and transferred onto PVDF membranes. After $1 \mathrm{~h}$ of blocking with 5\% nonfat dry milk in Tris-buffered saline (TBS), the membranes were incubated overnight at $4{ }^{\circ} \mathrm{C}$ with primary antibodies diluted in $5 \%$ nonfat milk/TBS. Following primary antibody incubation, the membranes were incubated with appropriate HRP-conjugated secondary antibodies. Immunoreactive bands were detected using an enhanced chemiluminescent substrate (Bio-Rad Laboratories) and imaged with a ChemiDoc MP Imager (Bio-Rad Laboratories).

\section{Small interfering RNA (siRNA) transfection}

To knock down endogenous ALK5, SMAD4, or KISS1 cells were transfected with $50 \mathrm{nM}$ ON-TARGETplus SMARTpool siRNA targeting a specific gene
(Dharmacon) using Lipofectamine RNAiMAX (Invitrogen). The siCONTROL NON-TARGETING pool siRNA (Dharmacon) was used as the transfection control.

\section{Invasion assay}

Transwell cell culture inserts $(8 \mu \mathrm{m}$ pore size, 24 wells, BD Biosciences) were coated with $1 \mathrm{mg} / \mathrm{mL}$ growth factor-reduced Matrigel (BD Biosciences). Cells $\left(1 \times 10^{5}\right.$ cells/insert) in DMEM/F12 medium supplemented with $0.1 \%$ FBS were incubated for $48 \mathrm{~h}$ against a gradient of $10 \%$ FBS. Noninvasive cells were removed with a cotton swab from the upper side of the membrane. Cells that penetrated the membrane were fixed with cold methanol. Cells were stained with crystal violet $(0.5 \%$, Sigma) for $30 \mathrm{~min}$ and subsequently washed thoroughly with tap water. Each experiment was performed with triplicate inserts. In each insert, five microscopic fields were photographed under an optical microscope, and the cell number was counted manually.

\section{ELISA assay}

The present study received approval and was performed in accordance with the approved guidelines from the Zhengzhou University Research Ethics Board (\#2020KY-164). Written informed consent was obtained from all patients before collecting serum samples. TGF- $\beta 1$ or kisspeptin protein levels in human serum samples were measured using an enzyme-linked immunosorbent assay (ELISA). The human TGF- $\beta 1$ ELISA Kit (Elabscience, \#E-EL-0162) and KISS1 ELISA Kit (Elabscience, \#E-ELH6099) were used following the manufacturer's protocol. The analytical sensitivity of TGF- $\beta 1$ ELISA was $0.1 \mathrm{ng} /$ $\mathrm{mL}$. Both intra-CV and inter-CV were $<10 \%$. The analytical sensitivity of KISS1 ELISA was $18.75 \mathrm{pg} / \mathrm{mL}$. Both intra-CV and inter-CV were $<10 \%$.

\section{Statistical analysis}

The results are presented as the mean \pm SEM or mean $\pm \mathrm{SD}$ of at least three independent experiments. All statistical analyses were analyzed by PRISM software. Multiple comparisons were analyzed using one-way ANOVA followed by Tukey's multiple comparison test. For experiments involving only two groups, the results were analyzed by $t$ test. A significant difference was defined as $p<0.05$.

\section{Results}

The expression of kisspeptin is upregulated by TGF- $\beta 1$ in human EVT cells

To examine the effect of TGF- $\beta 1$ on kisspeptin expression in human EVT cells, HTR-8/SVneo human EVT cells were treated with 5 or $10 \mathrm{ng} / \mathrm{mL}$ TGF- $\beta 1$ for 12 and $24 \mathrm{~h}$. As shown in Fig. 1A, treatment with 5 or $10 \mathrm{ng} / \mathrm{mL}$ 

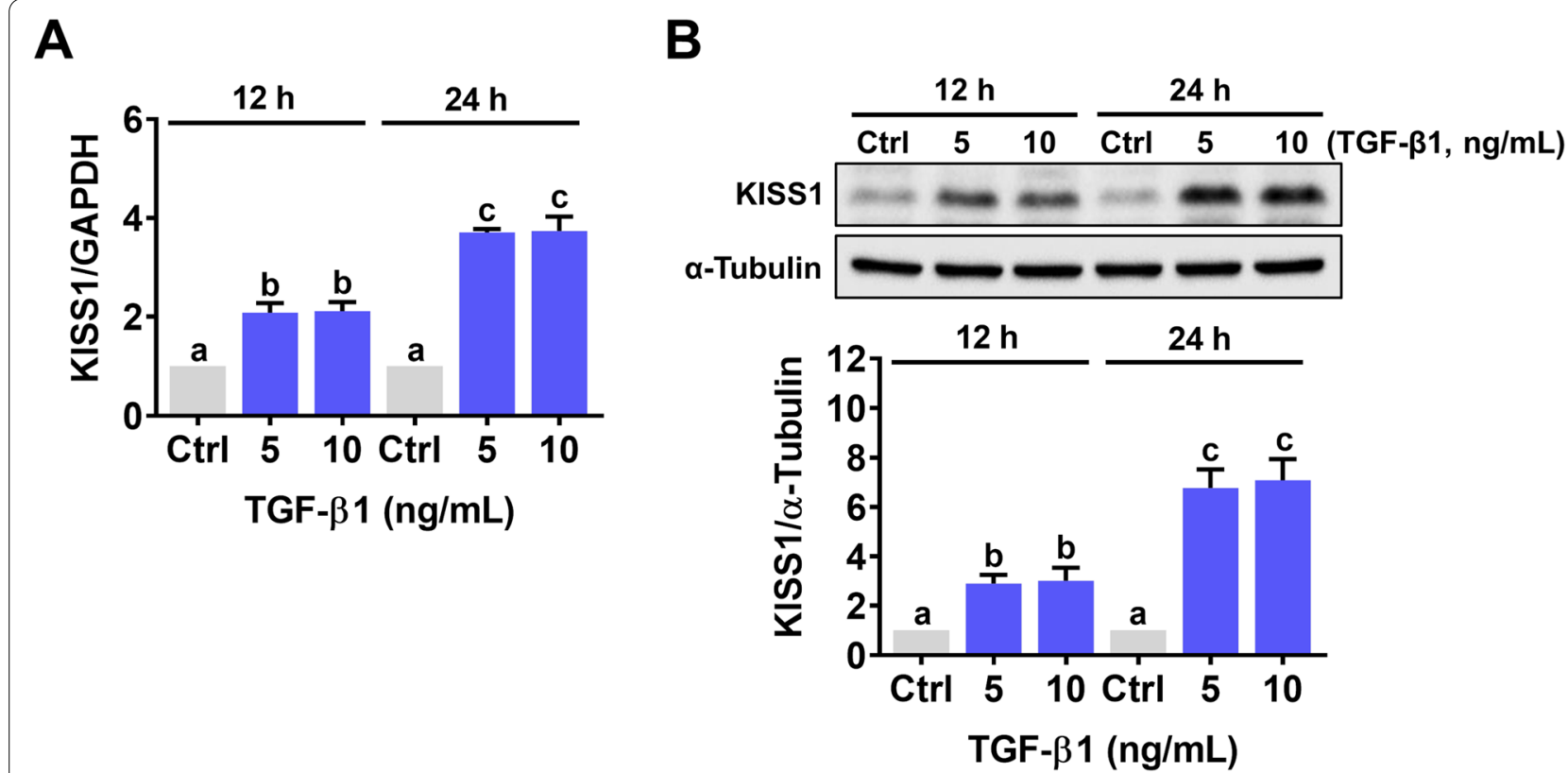

Fig. 1 TGF- $\beta 1$ upregulates kisspeptin expression in HTR-8/SVneo cells. A and $\mathbf{B}$ Cells were treated with 5 or $10 \mathrm{ng} / \mathrm{mL}$ TGF- $\beta 1$ for 12 and $24 \mathrm{~h}$. The kisspeptin mRNA levels $(\mathbf{A})$ and protein levels $(\mathbf{B})$ were examined by RT-qPCR and western blot, respectively. The results are expressed as the mean \pm SEM of at least three independent experiments. Values that are statistically different from one another $(p<0.05)$ are indicated by different letters

TGF- $\beta 1$ for $12 \mathrm{~h}$ slightly increased the mRNA levels of kisspeptin. The significant induction of kisspeptin mRNA expression was observed after $24 \mathrm{~h}$ of TGF- $\beta 1$ treatment. Treatments with 5 and $10 \mathrm{ng} / \mathrm{mL}$ TGF- $\beta 1$ showed a comparable stimulatory effect on kisspeptin mRNA levels. Western blot further confirmed the stimulatory effect of TGF- $\beta 1$ on kisspeptin protein levels in HTR-8/SVneo cells (Fig. 1B). SB431542 is a potent and specific TGF- $\beta$ type I receptor/ALK5 inhibitor [25]. Pre-treatment with SB431542 abolished the TGF- $\beta 1$-induced kisspeptin mRNA and protein levels in HTR-8/SVneo cells (Fig. 2A and $B)$. To avoid unknown off-target effects of pharmacological inhibitor and further confirm the requirement of the ALK5 in the TGF- $\beta 1$-induced kisspeptin expression, ALK5 specific siRNA was applied to knockdown ALK5 expression. As shown in Fig. $2 \mathrm{C}$ and $\mathrm{D}$, transfection of HTR-8/SVneo cells with ALK5 siRNA significantly downregulated endogenous ALK5 mRNA and protein levels. Meanwhile, the stimulatory effects of TGF- $\beta 1$ on kisspeptin mRNA and protein levels were abolished by the knockdown of ALK5.

TGF- $\beta 1$ induces kisspeptin expression in human EVT cells is SMAD-independent

In the canonical pathway, activation of ALK5 leads to phosphorylation of the downstream SMAD proteins, SMAD2/3. Phosphorylated SMAD2/3 then bind to the common-mediator SMAD4 and translocate into the nucleus where the SMAD complexes mediate TGF- $\beta$ regulated gene expression by binding to the SMADspecific binding element in the promoter region [16]. As expected, treatment of HTR-8/SVneo cells with $5 \mathrm{ng} /$ $\mathrm{mL}$ TGF- $\beta 1$ for 10,30 , or $60 \mathrm{~min}$ induced phosphorylation of SMAD2 and SMAD3 indicating their activations (Fig. 3A). To examine whether SMAD signaling is required for the TGF- $\beta 1$-induced kisspeptin expression, endogenous SMAD4 was knocked down by the siRNA transfection. Consistent with our previous study, knockdown of SMAD4 attenuated the TGF- $\beta 1$-induced connexin 43 (Cx43) expression in HTR-8/SVneo cells [26] (Fig. 3B). As shown in Fig. 3B and C, transfection of HTR-8/SVneo cells with SMAD4 siRNA significantly downregulated endogenous SMAD4 mRNA and protein levels. Interestingly, the knockdown of SMAD4 did not affect the stimulatory effects of TGF- $\beta 1$ on kisspeptin mRNA and protein levels. Collectively, these results indicate that the stimulatory effect of TGF- $\beta 1$ on kisspeptin expression is mediated by the SMAD-independent pathways in human EVT cells.

TGF- $\beta 1$ induces kisspeptin expression in human EVT cells through the ERK1/2 signaling pathway

ERK1/2 and PI3K/AKT are well-known non-canonical signaling pathways that mediate the biological function 

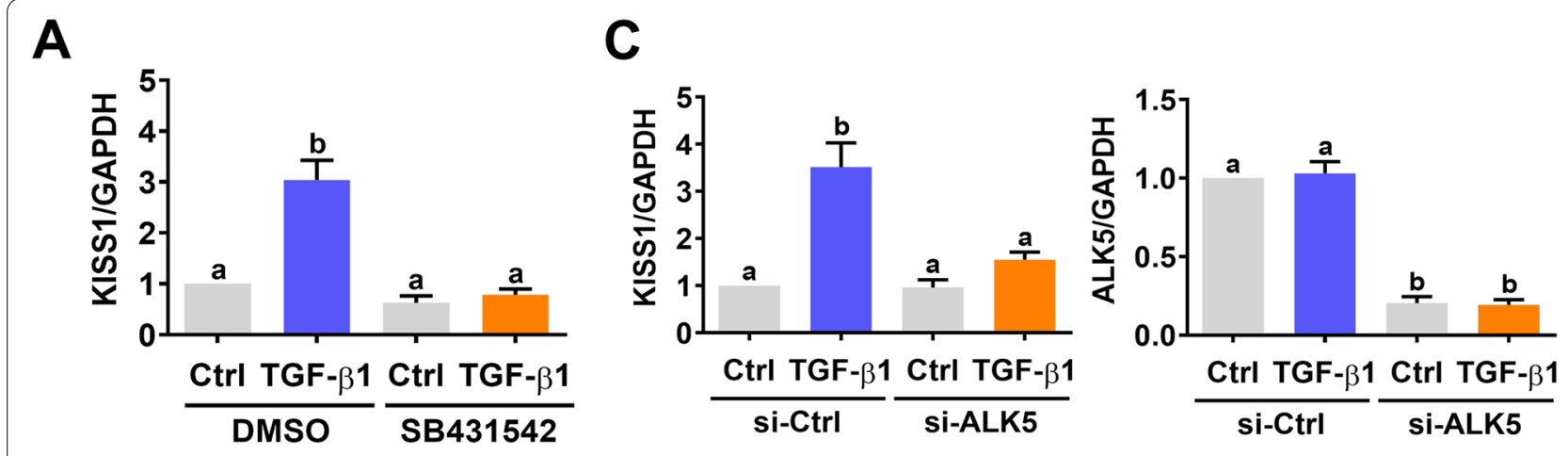

B
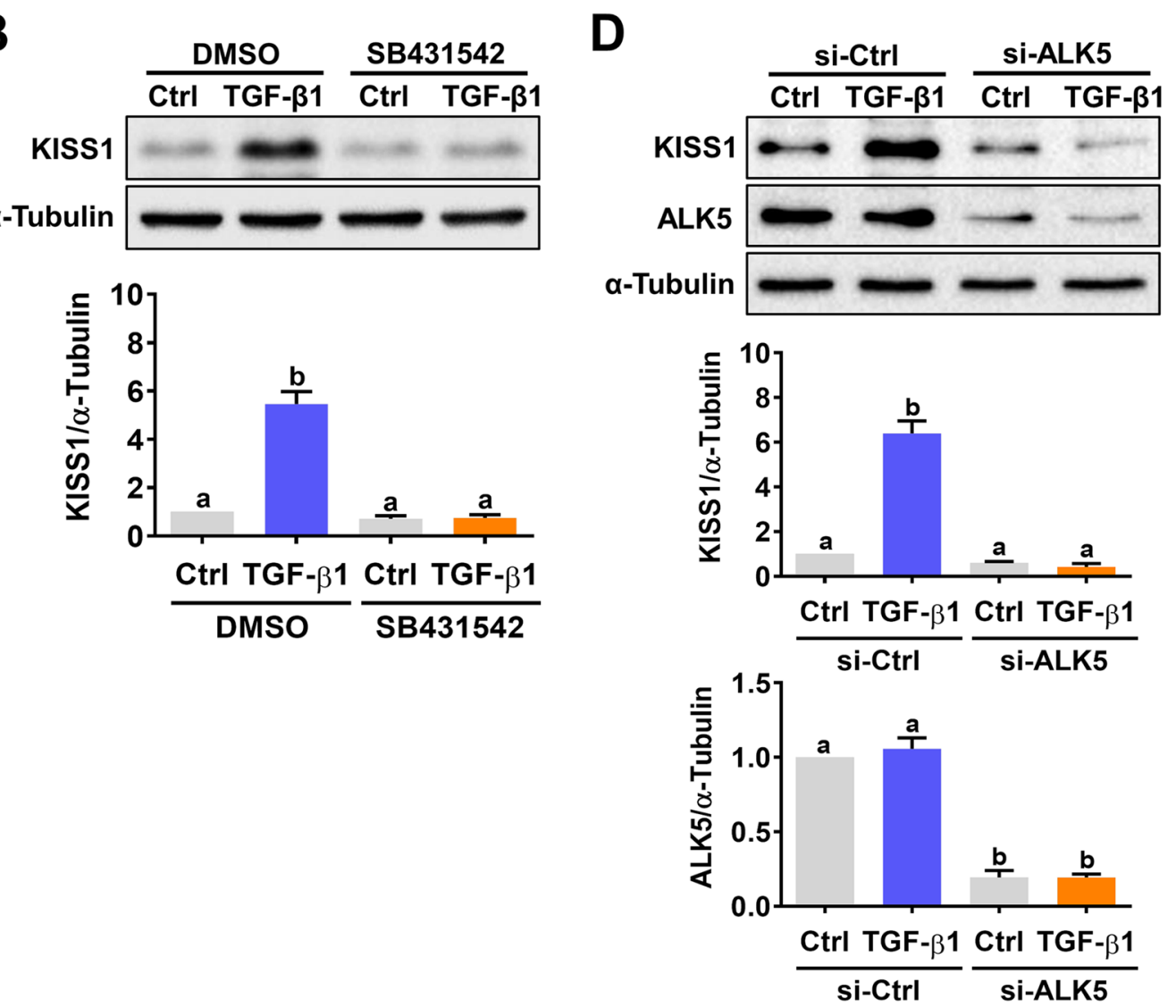

Fig. 2 ALK5 mediates TGF- 1 1-induced kisspeptin expression in HTR-8/SVneo cells. A and B Cells were pretreated with vehicle control (DMSO) or $10 \mu M$ SB431542 for $1 \mathrm{~h}$, and then treated with $5 \mathrm{ng} / \mathrm{mL}$ TGF- $\beta 1$ for $24 \mathrm{~h}$. The kisspeptin mRNA levels (A) and protein levels (B) were examined by RT-qPCR and western blot, respectively. C and D Cells were transfected with $50 \mathrm{nM}$ control siRNA (si-Ctrl) or ALK5 siRNA (si-ALK5) for $48 \mathrm{~h}$, and then treated with $5 \mathrm{ng} / \mathrm{mL}$ TGF- $\beta 1$ for $24 \mathrm{~h}$. The kisspeptin and ALK5 mRNA levels (C) and protein levels (D) were examined by RT-qPCR and western blot, respectively. The results are expressed as the mean \pm SEM of at least three independent experiments. Values that are statistically different from one another $(p<0.05)$ are indicated by different letters

(See figure on next page.)

Fig. 3 Activation of the SMAD signaling pathway is not involved in TGF- $\beta 1$-induced kisspeptin expression in HTR-8/SVneo cells. A Cells were treated with $5 \mathrm{ng} / \mathrm{mL}$ TGF- $\beta 1$ for 10, 30, and $60 \mathrm{~min}$. The levels of phosphorylated and total forms of SMAD2 and SMAD3 were determined by western blot. B and C Cells were transfected with $50 \mathrm{nM}$ control siRNA (si-Ctrl) or SMAD4 siRNA (si-SMAD4) for $48 \mathrm{~h}$, and then treated with $5 \mathrm{ng} / \mathrm{mL}$ TGF- $\beta 1$ for $24 \mathrm{~h}$. The kisspeptin, Cx43, and SMAD4 mRNA levels (B) and protein levels of kisspeptin and SMAD4 (C) were examined by RT-qPCR and western blot, respectively. The results are expressed as the mean \pm SEM of at least three independent experiments. Values that are statistically different from one another $(p<0.05)$ are indicated by different letters 


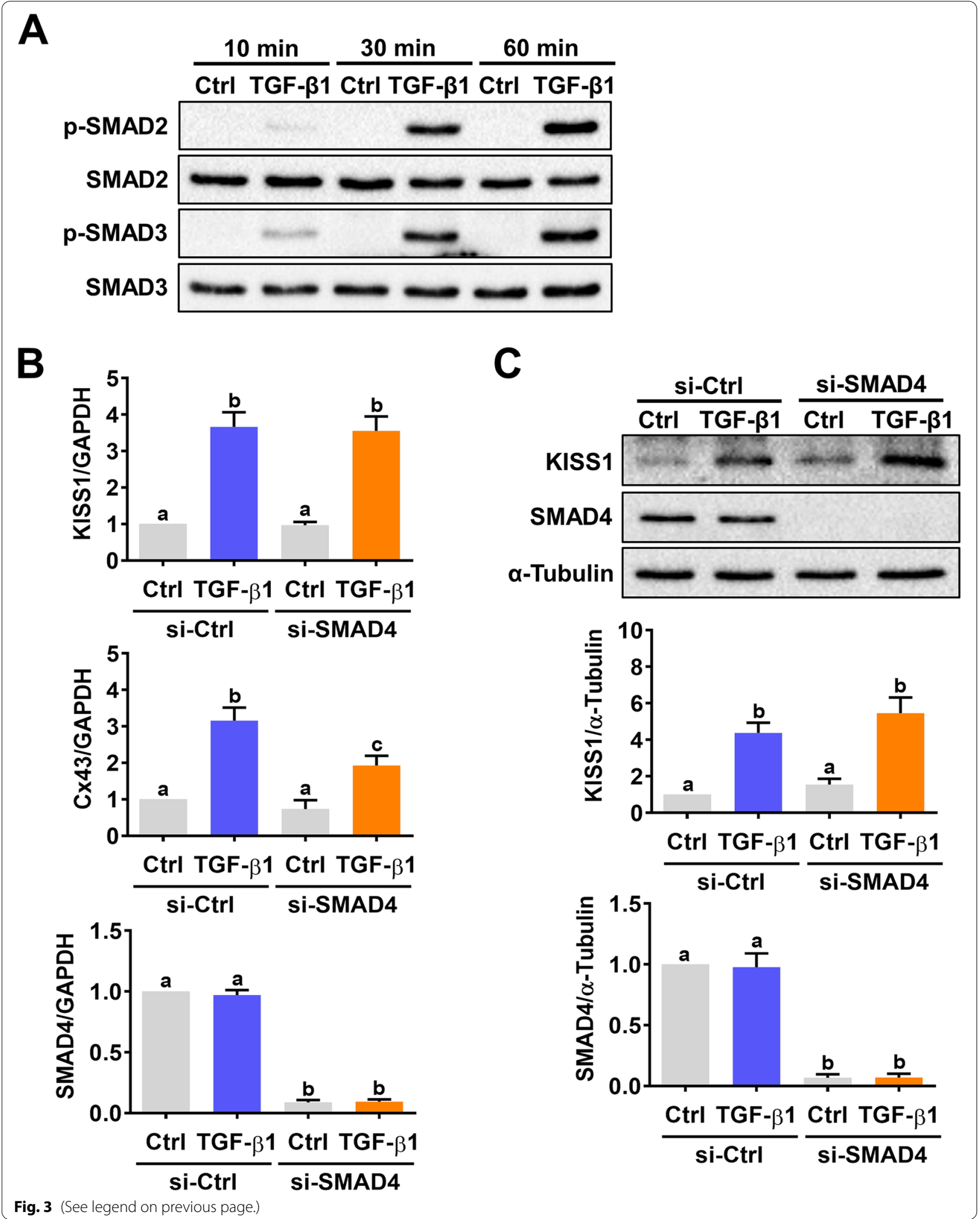




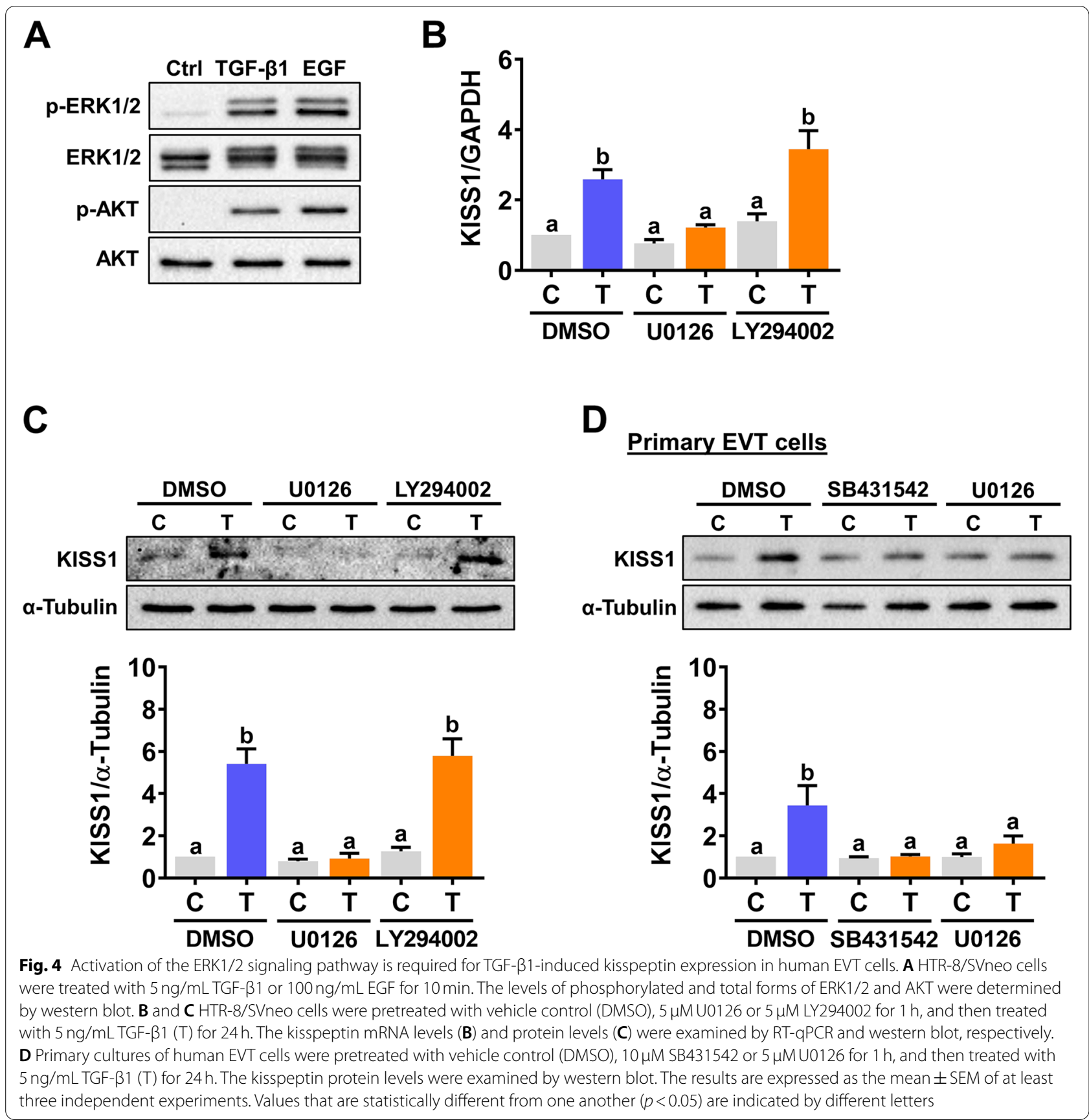

of TGF- $\beta 1$. As shown in Fig. 4A, treatment of HTR-8/ SVneo cells with $5 \mathrm{ng} / \mathrm{mL}$ TGF- $\beta 1$ for $10 \mathrm{~min}$ activates both ERK1/2 and AKT signaling pathways. We used epidermal growth factor (EGF) as positive controls for the activations of ERK $1 / 2$ and AKT. To examine the involvement of the ERK1/2 and AKT signaling pathways in the TGF- $\beta 1$-stimulated kisspeptin expression, the MEK inhibitor U0126, and PI3K inhibitor LY294002, were used to block their activations, respectively. As shown in
Fig. $4 \mathrm{~B}$ and $\mathrm{C}$, blocking the activation of ERK1/2 attenuated the TGF- $\beta 1$-induced kisspeptin mRNA and protein levels. Interestingly, inhibition of AKT did not affect the stimulatory effect of TGF- $\beta 1$ on both kisspeptin mRNA and protein levels. Consistent with the results obtained from HTR-8/SVneo cells, treatment with $5 \mathrm{ng} / \mathrm{mL}$ TGF$\beta 1$ upregulated kisspeptin protein levels in primary human EVT cells. In addition, the stimulatory effect of TGF- $\beta 1$ on kisspeptin protein levels in primary human 
EVT cells was abolished by the inhibition of ALK5 function and ERK1/2 signaling (Fig. 4D).

\section{Kisspeptin mediates TGF- $\beta 1$-inhibited human EVT cell invasion}

Matrigel transwell invasion assay results showed that treatment with $5 \mathrm{ng} / \mathrm{mL}$ TGF- $\beta 1$ or $1 \mu \mathrm{M}$ kisspeptin significantly inhibited the invasiveness of HTR-8/SVneo cells (Fig. 5A and B). To examine the involvement of kisspeptin in TGF- $\beta 1$-inhibited cell invasion, a siRNAmediated knockdown approach was applied to block the expression of kisspeptin. As shown in Fig. 5C, transfection of HTR-8/SVneo cells with kisspeptin not only downregulated the basal endogenous kisspeptin protein levels but also abolished the TGF- $\beta 1$-induced kisspeptin protein levels. Meanwhile, invasion assay results showed

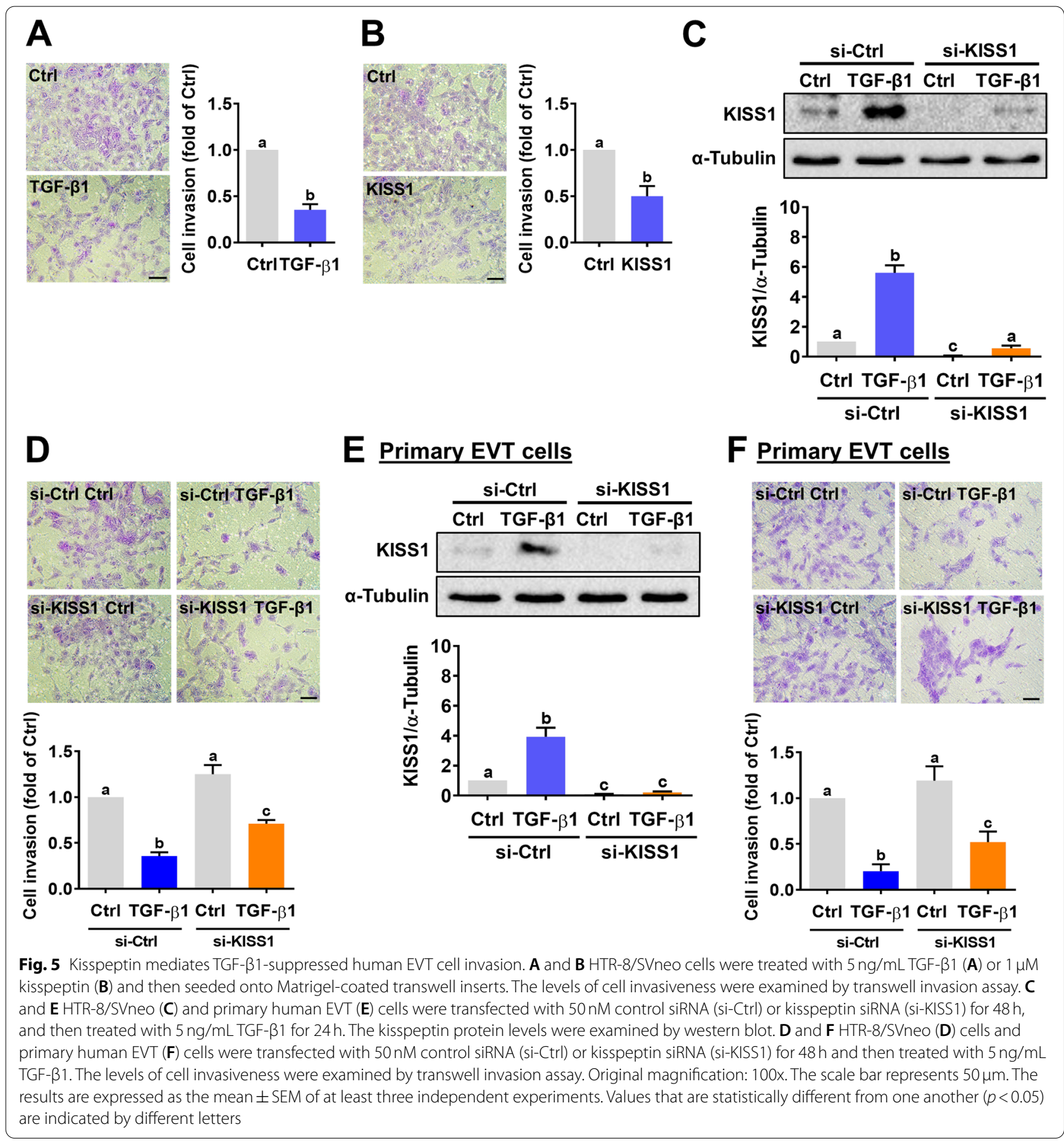


that the TGF- $\beta 1$-inhibited HTR-8/SVneo cell invasiveness was attenuated by the knockdown of kisspeptin (Fig. 5D). Consistent with the results obtained from HTR-8/SVneo cells, knockdown of kisspeptin reduced the inhibitory effect of TGF- $\beta 1$ on cell invasiveness in primary human EVT cells (Fig. 5E and F). Collectively, these results indicate that the TGF- $\beta 1$-inhibited human EVT cell invasion is mediated by kisspeptin.

\section{Serum TGF- $\beta 1$ and kisspeptin levels are upregulated in PE patients}

$\mathrm{PE}$ is a placental disease that can be caused by inadequate or incomplete trophoblast cell invasion which leads to insufficient blood flow to the uterus. Given the anti-invasive role of TGF- $\beta 1$ and kisspeptin in human EVT cells, we examined the serum levels of TGF- $\beta 1$ and kisspeptin in PE patients and compared them to those of women with normal pregnancies. Serum samples were collected from $25 \mathrm{PE}$ patients and 25 normal pregnant women of similar age and gestational age (Fig. 6A). As expected, BMI, systolic blood pressure (SBP), and diastolic blood pressure (DBP) in PE patients were significantly higher than those in normal controls (Fig. 6B). ELISA results showed that both serum levels of TGF- $\beta 1$ and kisspeptin were significantly upregulated in PE patients when compared to controls (Fig. $6 \mathrm{C}$ and D). Taken together, these results suggest that increased TGF- $\beta 1$ expression in PE patients could lead to poor EVT cell invasion by upregulating kisspeptin expression.

\section{Discussion}

The anti-invasive effects of TGF- $\beta 1$ and kisspeptin have been reported in human EVT cells. However, whether kisspeptin is regulated by TGF- $\beta 1$ and involved in TGF$\beta 1$-inhibited human EVT cell invasion remains unknown. In the present study, we reported that TGF- $\beta 1$ upregulated kisspeptin expression in human EVT line, HTR-8/ SVneo, and primary cultures of human EVT cells. Mechanically, we revealed that TGF- $\beta 1$ induced kisspeptin expression through the SMAD-independent ERK1/2 signaling pathway. In addition, the TGF- $\beta 1$-induced kisspeptin mediated the TGF- $\beta 1$-inhibited human EVT cell invasion. Moreover, we showed that serum levels of TGF$\beta 1$ and kisspeptin were upregulated in PE patients.

It is known that kisspeptin is expressed in the hypothalamus where affects the hypothalamic-pituitary-gonadal axis and reproductive function by regulating gonadotropin-releasing hormone (GnRH) secretion [27]. In addition, kisspeptin plays important role in the pathogenesis of various human cancers $[28,29]$. To date, most of the mechanisms that mediate the regulation of KISS1 gene expression are identified in the hypothalamic context of animal models and cancers. Although kisspeptin is highly expressed in the human placenta [30], the underlying molecular mechanism that mediates its expression there remains poorly defined. Previous studies have shown that estrogen, GnRH, neurokinin B, and glucocorticoids can stimulate KISS1 gene expression in human placental cells $[31,32]$. In the present study, we showed that both mRNA and protein levels of kisspeptin in human EVT cells were upregulated by the treatment of TGF- $\beta 1$. Interestingly, we revealed that SMAD signaling was not required for the TGF- $\beta 1$-induced kisspeptin expression which is different from the previous findings that the stimulatory effect of TGF- $\beta 1$ on kisspeptin is mediated by SMAD2 in triple-negative breast cancer cells [19]. These results suggest that the underlying mechanisms that mediate the TGF- $\beta 1$-induced kisspeptin expression are in a cell-type dependent manner. In triple-negative breast cancer cells, melatonin induces kisspeptin expression by increasing the expression and transcriptional activation of GATA3 [33]. Activation of Ras-ERK1/2 cascade regulates GATA3-mediated gene expressions by increasing GATA3 protein stability [34]. Our results showed that activation of the ERK1/2 signaling pathway is required for the TGF- $\beta 1$-induced kisspeptin expression. However, whether GATA3 is involved in TGF- $\beta 1$-stimulated kisspeptin expression in human EVT cells remains unknown and warrants further investigations.

Matrix metalloproteinases (MMPs)-mediated extracellular matrix degradation or remodeling is a necessary event for the human EVT cell invasion [35, 36]. TGF- $\beta 1$ has been shown to inhibit EVT cell invasion by downregulating the expression and activity of MMPs [21, 37]. Similarly, MMPs mediate kisspeptin-inhibited EVT cell invasion [10]. Here, we showed that knockdown of kisspeptin attenuated TGF- $\beta 1$-inhibited HTR-8/SVneo cell invasion. Collectively, these results indicate that TGF$\beta 1 /$ kisspeptin/MMPs plays important role in regulating human EVT cell invasion. In rat ovaries, injection of human chorionic gonadotropin increases the kisspeptin mRNA levels, and this stimulatory effect is completely abolished by the inhibition of cyclooxygenase-2 (COX2) [38]. These results indicate that kisspeptin is one of the downstream targets of COX-2/prostaglandins. Our previous study has shown that TGF- $\beta 1$ inhibits HTR-8/ SVneo cell invasion by upregulating the expression of COX-2 [39]. Therefore, although it needs to be confirmed, it seems plausible that COX-2 may mediate the TGF- $\beta 1$-induced kisspeptin expression in human EVT cells. Interestingly, a TaqMan gene array shows that treatment of kisspeptin upregulates TGF- $\beta 1$ mRNA levels in the first-trimester human trophoblast cells [10]. These findings together with our results suggest the reciprocal regulation of TGF- $\beta 1$ and kisspeptin may exist in the human placenta. 


\section{A}
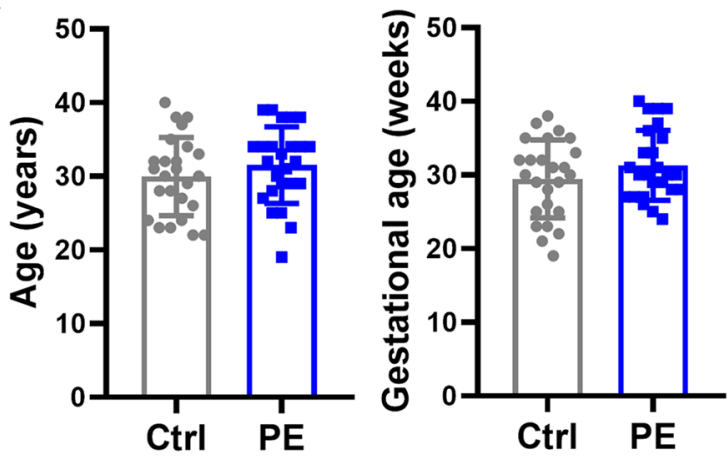

B
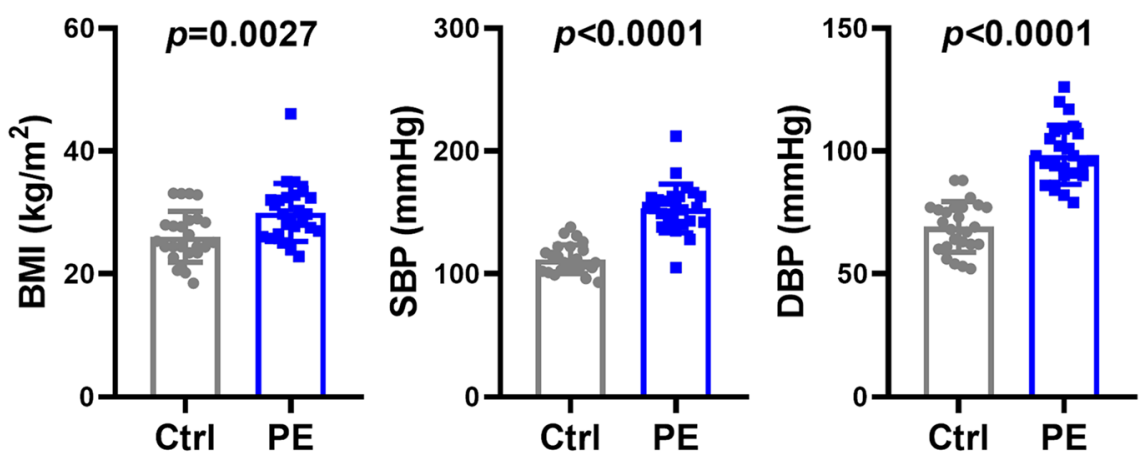

C

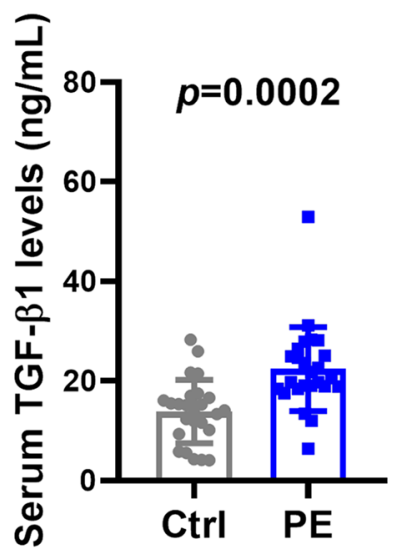

D

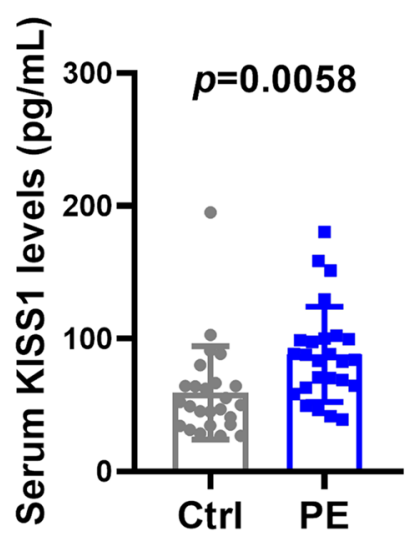

Fig. 6 Serum levels of TGF- $\beta 1$ and kisspeptin are upregulated in patients. A and B Serum samples were collected from 25 PE patients and 25 normal pregnant women of similar age and gestational age. The age and gestational age of the included patients are presented (A). BMI, systolic blood pressure (SBP), and diastolic blood pressure (DBP) were measured (B). C Serum levels of TGF- $\beta 1$ were measured by ELISA. D Serum levels of KISS1 were measured by ELISA. The results are expressed as the mean \pm SD

Insufficient EVT cell invasion is one of the major characteristics of PE. Placental TGF- $\beta 1$ levels are significantly higher in PE patients than controls [40]. In the present study, we showed that serum levels TGF- $\beta 1$ are significantly elevated in patients with PE when compared to patients with normal pregnancy which is consistent with many previous studies [40-45]. However, few studies report that serum levels of TGF- $\beta 1$ are not varied between control and PE patients [46-48]. One study reveals the opposite observation that serum levels of 
TGF- $\beta 1$ are reduced in PE patients [49]. All these contradictory reports are probably due to differences in sample selection, collection, and preparation as well as differences in methodology. In addition to TGF- $\beta 1$, our results showed that the serum levels of kisspeptin were increased in PE patients when compared to normal controls. It is interesting to note that the elevation of serum kisspeptin levels is conflicted with previous studies showing that serum kisspeptin levels are reduced in PE patients [50, 51]. Regardless of serum kisspeptin, the protein levels of kisspeptin are significantly upregulated in the placentas of PE patients [52]. Taken together, these clinical data support our in vitro experimental results that TGF- $\beta 1$ inhibits human EVT cell invasion by upregulating kisspeptin expression.

\section{Conclusions}

In summary, the present study demonstrates that exposure to TGF- $\beta 1$ stimulates kisspeptin expression in HTR-8/SVneo and human primary EVT cells. This effect is mediated by the activation of the SMAD-independent ERK1/2 signaling pathway. In addition, the induction of kisspeptin is involved in TGF- $\beta 1$-inhibited human EVT cell invasion. Moreover, both TGF- $\beta 1$ and kisspeptin levels in serum are upregulated in PE patients. These results reveal the physiological role and underlying mechanism of TGF- $\beta 1$ in the regulation of kisspeptin expression in human EVT cells and might help develop new strategies for the treatment of placental diseases.

\begin{abstract}
Abbreviations
Cx43: Connexin 43; COX-2: Cyclooxygenase-2; DBP: Diastolic blood pressure; ELISA: Enzyme-linked immunosorbent assay; EGF: Epidermal growth factor; EVT: Extravillous cytotrophoblast; GnRH: Gonadotropin-releasing hormone; MMPs: Matrix metalloproteinases; PE: Preeclampsia; SBP: Systolic blood pressure; TGF- $\beta 1$ : Transforming growth factor-beta 1; TBS: Tris-buffered saline.
\end{abstract}

\section{Acknowledgments}

We thank all patients and staff at the Center for Reproductive Medicine of the First Affiliated Hospital of Zhengzhou University, for their contributions to the clinical sample collections.

\section{Authors' contributions}

LF, JCC, and YPS contributed to the study design, data analysis, interpretation of data, and manuscript writing. LF and YY contributed to the manuscript drafting. $L F, Y Y, Y G, Z W, Z W$, and SY performed the experiments, collected and organized clinical samples, and prepared the figures. The author(s) read and approved the final manuscript.

\section{Funding}

This work was supported by the National Key R\&D Program (2019YFA 0110900) and the International (Regional) Cooperation and Exchange Projects (81820108016) from the National Natural Science Foundation of China to Ying-Pu Sun. This work was also supported by the Research Fund for International Young Scientists from the National Natural Science Foundation of China (32050410302) and by the Henan Province Medical Science and Technique R\&D Program (SBGJ202002046) to Jung-Chien Cheng, as well as by the operating grant from the National Natural Science Foundation of China (32070848) and by the Henan Province Medical Science and Technique R\&D Program (SBGJ202002052) to Lanlan Fang.

\section{Availability of data and materials}

The data that support the findings of this study are available from the corresponding author upon reasonable request.

\section{Declarations}

Ethics approval and consent to participate

The studies regarding the clinical samples received approval and were carried out in accordance with the approved guidelines from the Zhengzhou University Research Ethics Board.

\section{Consent for publication}

Not applicable.

\section{Competing interests}

The authors declare that they have no competing interests.

Received: 4 November 2021 Accepted: 22 January 2022

Published online: 31 January 2022

References

1. Aplin JD. Implantation, trophoblast differentiation and haemochorial placentation: mechanistic evidence in vivo and in vitro. J Cell Sci. 1991;99(Pt 4):681-92.

2. Knoeller S, Lim E, Aleta L, Hertwig K, Dudenhausen JW, Arck PC. Distribution of immunocompetent cells in decidua of controlled and uncontrolled (choriocarcinoma/hydatidiform mole) trophoblast invasion. Am J Reprod Immunol. 2003;50:41-7.

3. Lim KH, Zhou Y, Janatpour M, McMaster M, Bass K, Chun SH, et al. Human cytotrophoblast differentiation/invasion is abnormal in pre-eclampsia. Am J Pathol. 1997:151:1809-18.

4. Steegers EA, von Dadelszen P, Duvekot JJ, Pijnenborg R. Pre-eclampsia. Lancet. 2010;376:631-44.

5. Lee JH, Miele ME, Hicks DJ, Phillips KK, Trent JM, Weissman BE, et al. KiSS-1, a novel human malignant melanoma metastasis-suppressor gene. J Natl Cancer Inst. 1996;88:1731-7.

6. Horikoshi Y, Matsumoto H, Takatsu Y, Ohtaki T, Kitada C, Usuki S, et al. Dramatic elevation of plasma metastin concentrations in human pregnancy: metastin as a novel placenta-derived hormone in humans. J Clin Endocrinol Metab. 2003;88:914-9.

7. Oakley AE, Clifton DK, Steiner RA. Kisspeptin signaling in the brain. Endocr Rev. 2009;30:713-43.

8. Janneau JL, Maldonado-Estrada J, Tachdjian G, Miran I, Motte N, Saulnier $P$, et al. Transcriptional expression of genes involved in cell invasion and migration by normal and tumoral trophoblast cells. J Clin Endocrinol Metab. 2002;87:5336-9.

9. Roseweir AK, Katz AA, Millar RP. Kisspeptin-10 inhibits cell migration in vitro via a receptor-GSK3 beta-FAK feedback loop in HTR8SVneo cells. Placenta. 2012;33:408-15.

10. Francis VA, Abera AB, Matjila M, Millar RP, Katz AA. Kisspeptin regulation of genes involved in cell invasion and angiogenesis in first trimester human trophoblast cells. PLoS One. 2014;9:e99680.

11. Bilban M, Ghaffari-Tabrizi N, Hintermann E, Bauer S, Molzer S, Zoratti C, et al. Kisspeptin-10, a KiSS-1/metastin-derived decapeptide, is a physiological invasion inhibitor of primary human trophoblasts. J Cell Sci. 2004;117:1319-28.

12. Fang $L$, Gao $Y$, Wang $Z$, Li Y, Yan $Y$, Wu Z, et al. EGF stimulates human trophoblast cell invasion by downregulating ID3-mediated KISS1 expression. Cell Commun Signal. 2021;19:101.

13. Gomes VCL, Sones JL. From inhibition of trophoblast cell invasion to proapoptosis: what are the potential roles of kisspeptins in preeclampsia? Am J Physiol Regul Integr Comp Physiol. 2021;321:R41-8.

14. Blobe GC, Schiemann WP, Lodish HF. Role of transforming growth factor beta in human disease. N Engl J Med. 2000;342:1350-8.

15. Shi Y, Massague J. Mechanisms of TGF-beta signaling from cell membrane to the nucleus. Cell. 2003;113:685-700.

16. Heldin CH, Miyazono K, ten Dijke P. TGF-beta signalling from cell membrane to nucleus through SMAD proteins. Nature. 1997;390:465-71. 
17. Zhang YE. Non-Smad pathways in TGF-beta signaling. Cell Res. 2009;19:128-39.

18. Jones RL, Stoikos C, Findlay JK, Salamonsen LA. TGF-beta superfamily expression and actions in the endometrium and placenta. Reproduction. 2006:132:217-32

19. Tian J, Al-Odaini AA, Wang Y, Korah J, Dai M, Xiao L, et al. KiSS1 gene as a novel mediator of TGFbeta-mediated cell invasion in triple negative breast cancer. Cell Signal. 2018;42:1-10.

20. Cheng JC, Chang HM, Leung PC. Transforming growth factor-beta1 inhibits trophoblast cell invasion by inducing Snail-mediated down-regulation of vascular endothelial-cadherin protein. J Biol Chem. 2013;288:33181-92.

21. Lash GE, Otun HA, Innes BA, Bulmer JN, Searle RF, Robson SC. Inhibition of trophoblast cell invasion by TGFB1, 2, and 3 is associated with a decrease in active proteases. Biol Reprod. 2005;73:374-81.

22. Karmakar S, Das C. Regulation of trophoblast invasion by IL-1 beta and TGF-beta1. Am J Reprod Immunol. 2002;48:210-9.

23. Cheng JC, Chang HM, Leung PCK. TGF-beta1 inhibits human trophoblast cell invasion by upregulating connective tissue growth factor expression. Endocrinology. 2017;158:3620-8.

24. Graham CH, Hawley TS, Hawley RG, MacDougall JR, Kerbel RS, Khoo N, et al. Establishment and characterization of first trimester human trophoblast cells with extended lifespan. Exp Cell Res. 1993;206:204-11.

25. Inman GJ, Nicolas FJ, Callahan JF, Harling JD, Gaster LM, Reith AD, et al SB-431542 is a potent and specific inhibitor of transforming growth factor-beta superfamily type I activin receptor-like kinase (ALK) receptors ALK4, ALK5, and ALK7. Mol Pharmacol. 2002;62:65-74.

26. Cheng JC, Chang HM, Fang L, Sun YP, Leung PC. TGF-beta1 up-regulates connexin43 expression: a potential mechanism for human trophoblast cell differentiation. J Cell Physiol. 2015;230:1558-66.

27. Roseweir AK, Millar RP. The role of kisspeptin in the control of gonadotrophin secretion. Hum Reprod Update. 2009;15:203-12.

28. Harihar S, Ray S, Narayanan S, Santhoshkumar A, Ly T, Welch DR. Role of the tumor microenvironment in regulating the anti-metastatic effect of KISS1. Clin Exp Metastasis. 2020;37:209-23.

29. Guzman S, Brackstone M, Radovick S, Babwah AV, Bhattacharya MM KISS1/KISS1R in cancer: friend or foe? Front Endocrinol (Lausanne). 2018;9:437.

30. Ohtaki T, Shintani Y, Honda S, Matsumoto H, Hori A, Kanehashi K, et al. Metastasis suppressor gene KiSS-1 encodes peptide ligand of a G-protein-coupled receptor. Nature. 2001;411:613-7.

31. Oride A, Kanasaki H, Mijiddorj T, Sukhbaatar U, Ishihara T, Kyo S. Regulation of kisspeptin and gonadotropin-releasing hormone expression in rat placenta: study using primary cultures of rat placental cells. Reprod Biol Endocrinol. 2015:13:90

32. Mark PJ, Jones ML, Lewis JL, Waddell BJ, Smith JT. Kiss1 and Kiss1r mRNA expression in the rat placenta: changes with gestational age and regulation by glucocorticoids. Placenta. 2013;34:657-62.

33. Kim TH, Cho SG. Melatonin-induced KiSS1 expression inhibits triplenegative breast cancer cell invasiveness. Oncol Lett. 2017;14:2511-6.

34. Yamashita M, Shinnakasu R, Asou H, Kimura M, Hasegawa A, Hashimoto $K$, et al. Ras-ERK MAPK cascade regulates GATA3 stability and Th2 differentiation through ubiquitin-proteasome pathway. J Biol Chem. 2005:280:29409-19.

35. Nagase H, Woessner JF Jr. Matrix metalloproteinases. J Biol Chem. 1999:274:21491-4

36. Cohen M, Meisser A, Bischof P. Metalloproteinases and human placental invasiveness. Placenta. 2006;27:783-93.

37. Meisser A, Chardonnens D, Campana A, Bischof P. Effects of tumour necrosis factor-alpha, interleukin-1 alpha, macrophage colony stimulating factor and transforming growth factor beta on trophoblastic matrix metalloproteinases. Mol Hum Reprod. 1999;5:252-60.

38. Gaytan F, Gaytan M, Castellano JM, Romero M, Roa J, Aparicio B, et al. KiSS-1 in the mammalian ovary: distribution of kisspeptin in human and marmoset and alterations in KiSS-1 mRNA levels in a rat model of ovulatory dysfunction. Am J Physiol Endocrinol Metab. 2009;296:E520-31.

39. Yi Y, Cheng JC, Klausen C, Leung PCK. TGF-beta1 inhibits human trophoblast cell invasion by upregulating cyclooxygenase-2. Placenta. 2018:68:44-51.

40. Benian A, Madazli R, Aksu F, Uzun H, Aydin S. Plasma and placental levels of interleukin-10, transforming growth factor-beta1, and epithelial-cadherin in preeclampsia. Obstet Gynecol. 2002;100:327-31.
41. Peracoli MT, Menegon FT, Borges VT, de Araujo Costa RA, Thomazini-Santos IA, Peracoli JC. Platelet aggregation and TGF-beta(1) plasma levels in pregnant women with preeclampsia. J Reprod Immunol. 2008;79:79-84.

42. Enquobahrie DA, Williams MA, Qiu C, Woelk GB, Mahomed K. Maternal plasma transforming growth factor-beta1 concentrations in preeclamptic and normotensive pregnant Zimbabwean women. J Matern Fetal Neonatal Med. 2005;17:343-8.

43. Madazli R, Aydin S, Uludag S, Vildan O, Tolun N. Maternal plasma levels of cytokines in normal and preeclamptic pregnancies and their relationship with diastolic blood pressure and fibronectin levels. Acta Obstet Gynecol Scand. 2003;82:797-802.

44. Naicker T, Khedun SM, Moodley J. Transforming growth factor beta(1) levels in platelet depleted plasma in African women with pre-eclampsia. J Obstet Gynaecol. 2002;22:279-82.

45. Djurovic S, Schjetlein R, Wisloff F, Haugen G, Husby H, Berg K. Plasma concentrations of $L p(a)$ lipoprotein and TGF-beta1 are altered in preeclampsia. Clin Genet. 1997;52:371-6.

46. ElMonier AA, El-Boghdady NA, Abdelaziz MA, Shaheen AA. Association between endoglin/transforming growth factor beta receptors 1, 2 gene polymorphisms and the level of soluble endoglin with preeclampsia in Egyptian women. Arch Biochem Biophys. 2019;662:7-14.

47. Huber A, Hefler L, Tempfer C, Zeisler H, Lebrecht A, Husslein P. Transforming growth factor-beta 1 serum levels in pregnancy and pre-eclampsia. Acta Obstet Gynecol Scand. 2002;81:168-71.

48. Hennessy A, Orange S, Willis N, Painter DM, Child A, Horvath JS. Transforming growth factor-beta 1 does not relate to hypertension in preeclampsia. Clin Exp Pharmacol Physiol. 2002;29:968-71.

49. Clausen T, Djurovic S, Reseland JE, Berg K, Drevon CA, Henriksen T. Altered plasma concentrations of leptin, transforming growth factor-beta(1) and plasminogen activator inhibitor type 2 at 18 weeks of gestation in women destined to develop pre-eclampsia. Circulating markers of disturbed placentation? Placenta. 2002;23:380-5.

50. Cetkovic A, Miljic D, Ljubic A, Patterson M, Ghatei M, Stamenkovic J, et al. Plasma kisspeptin levels in pregnancies with diabetes and hypertensive disease as a potential marker of placental dysfunction and adverse perinatal outcome. Endocr Res. 2012;37:78-88.

51. Armstrong RA, Reynolds RM, Leask R, Shearing CH, Calder AA, Riley SC. Decreased serum levels of kisspeptin in early pregnancy are associated with intra-uterine growth restriction and pre-eclampsia. Prenat Diagn. 2009;29:982-5.

52. Kapustin RV, Drobintseva AO, Alekseenkova EN, Onopriychuk AR, Arzhanova ON, Polyakova VO, et al. Placental protein expression of kisspeptin-1 (KISS1) and the kisspeptin-1 receptor (KISS1R) in pregnancy complicated by diabetes mellitus or preeclampsia. Arch Gynecol Obstet. 2020;301:437-45.

\section{Publisher's Note}

Springer Nature remains neutral with regard to jurisdictional claims in published maps and institutional affiliations.
Ready to submit your research? Choose BMC and benefit from:
- fast, convenient online submission
- thorough peer review by experienced researchers in your field
- rapid publication on acceptance
- support for research data, including large and complex data types
- gold Open Access which fosters wider collaboration and increased citations
- maximum visibility for your research: over 100M website views per year

\section{At $\mathrm{BMC}$, research is always in progress.}

Learn more biomedcentral.com/submissions 